\title{
STATISTICS IN ISLAMIC SCRIPTURES AND LEGACY
}

\author{
Qazi M.Ali* \\ Mohammad Omar Farooq**
}

\begin{abstract}
Statistics as a modern discipline has emerged and developed as part of the development of scientific inquiry. While Islamic civilisation has contributed to many key areas of modern knowledge, statistics is one area that has rarely been explored in this context. This paper examines the concept of statistics in Islamic scriptures, particularly the Qur'an, and how the concept has evolved in the history of Islamic civilisation. Evidence presented in the paper sheds important light on how close the modern concept of statistics is to the term al-ihsa' in the Qur'an.
\end{abstract}

Keywords: Statistics, Islam, Ihsa', Islamic history, Social Research, Ibn Khaldun.

\section{Introduction}

Statistics has been used by scholars of religion for a fairly long time. First, statistical methodology was used to verify the authorship of religious texts. Secondly, it was utilised to study the historical aspects of religious movements. Thirdly, some statisticians looked for statistical and probabilistic ideas in religious texts. Keeping in view the third aspect, this paper attempts to explore the Islamic scriptures, namely the Qur' an and hadith (the traditions of the Prophet of Islam), for the use of the concept 'statistics' as it is understood today.

While this usage of the concept has relevance from the perspective of hermeneutics, it also has heuristic applications. Like other parts of the world, the Muslim world has had various experiences of statistical measurements and applications. Yet, statistics as a subject remains a neglected one in the Muslim scholarly tradition. This paper is expected to pave the way for a better understanding of the concept of statistics from the Islamic scriptural perspective. This may also help trace the applied side of statistics in the Muslim world throughout history.

\section{Conceptualising the premises}

Walter Wilcox collated 115 definitions of 'statistics' given by different scholars in European languages during the period 1749-1934. ${ }^{1}$ A modern definition of statistics has evolved into something closer to the following, given in the 
Encyclopedia Britannica: "the art and science of gathering, analyzing and making inferences from data." ${ }^{2}$ It is also described as "the collection of data sets, and extraction and presentation of the information they contain." ${ }^{3}$ In examining the usage of the term 'statistics' in the religious scriptures of Islam, the abovementioned definitions will be used for comparative reference.

\section{Statistics and religion}

An entry in the Encyclopedia of Statistical Sciences entitled 'Statistics in Religious Studies' contains a brief account of the topic along with a bibliography. ${ }^{4}$ For example, A. S. Hasofer explores the occurrence of probability notions as well as a variety of random mechanisms in Talmudic literature. ${ }^{5}$ N. L. Rabinovitch studies both the ancient and medieval periods from the perspective of probability and statistical inference. ${ }^{6}$ Adam and Reucher studies Isaiah. ${ }^{7}$ A. M. Honroe examines the issue of synoptism in Christian scripture. ${ }^{8}$ Thus, in the context of the relationship between statistics and religious studies, one finds several key areas of statistics explored and/or applied.

A major application of statistics to religious studies occurs in the study of religious literature ... Compilation of data from religious writings can be dated to the work of the Masoretes, Jewish scribes who worked during the sixth through tenth centuries and were concerned with accurate preservation of the Hebrew Bible. ${ }^{9}$

Many of these studies were limited to basic data gathering and organisation, such as word counts, letter counts, occurrence of certain words, etc. without applying any statistical analysis. Many such works later applied statistical techniques of inference.

[T] he use of formal statistical analysis to explicate such [scripturerelated] hypotheses did not occur until the mid-twentieth century. Following Wake, Morton and his colleagues applied statistical methods to the Pauline Epistles ... He measured such variables as sentence length and the frequency of occurrence of specific words, and compared of the writings traditionally attributed to Paul with each other and with other classical Greek writings. ${ }^{10}$

Gradually, a more comprehensive application of statistical analysis was observed in various areas of religious studies.

[Another] area of relationship between statistics and religious studies concerns application of statistical methodology in sociological, historical, or archeological investigations in religious studies. Three 
journals... are dedicated to such investigations, although similar studies appear in a wide variety of sources. ${ }^{11}$

\section{Statistics, social research and Islamic discourse}

With such a robust application of statistics to Jewish and Christian scriptures, ${ }^{12}$ one question naturally arises: what has been the relationship, if any, of this subject to Islam and Islamic scriptures? For many centuries Islamic civilisation outshone other civilisations over vast parts of the world. Islamic civilisation was a vibrant one, politically, economically, socially, culturally, intellectually and technologically. While many statistical concepts have taken their current shape only in modern times, many basic or essential aspects could not have been avoided in an advanced civilisation like that of Islam. Yet, one observes a paucity of studies in this area. Such paucity appears paradoxical, because the notion of statistics, as it has evolved in modern times is very close to a similar notion appearing in the Qur'an and hadith, the two primary scriptural sources of Islam.

For those who are unfamiliar with the primary scriptural sources of Islam, a brief explanation might be helpful. According to Islamic creed, the Qur'an was revealed verbatim from God to the last Messenger, Muhammad, through the archangel Jibril (Gabriel). The Prophet Muhammad received these revelations over a period of twenty-three years, when they were memorised by numerous of his faithful followers, and also written down. Hadith, which are the second primary source, contain records of the words and deeds of the Prophet. Over several centuries these narrations took the form of a number of compilations, the most trusted ones being Sahih al-Bukhari ${ }^{13}$ and Sahih Muslim. ${ }^{14}$ If any Islamic practice or precept is not mentioned or elaborated upon in the Qur'an, Muslims must turn to the hadith for detailed guidance based on the fact that the Prophet is uswatun hasana (the best example). Apart from these two primary scriptural sources, there are secondary sources of Islamic law and jurisprudence, which includes ijma' (consensus) and qiyas (analogical reasoning).

Exploring the literature on statistics and religious studies, there is hardly any study focused on Islam, mainly because legalism and theology have gained an overwhelming dominance in the discourse on this religion. Muslim scholars who upheld the rationalistic and intellectual dimensions of textual analysis were ignored or even rejected by the so-called mainstream Muslim community. Thus, more Muslims are familiar with the names and works of luminaries of Islam, such as Imam Abu Hanifa (d. 767 AD), Imam Malik (d. 795 AD), Imam Shafi'i (d. 820 AD), Imam Ahmad ibn Hanbal (d. 855 AD), Imam Ghazali (d. 1111 AD), Imam Ibn Taymiyya (d. $1328 \mathrm{AD}$ ) and so on, then they are with rationalists like al-Kindi (d. 870 AD), al-Biruni (d. 1048 AD), Ibn Rushd (d. 1198 AD) or Ibn 
Khaldun (d. 1406 AD). Many scholars in the latter group were not only ignored, but religiously denounced. ${ }^{15}$

The orthodox view culminated in the position of Imam al-Ghazali, whose impact may have seriously constrained the development of Muslim minds in the rational or scientific fields. Al-Ghazali observed: "Even if geometry and mathematics do not contain notions that are harmful to religious belief, we nevertheless fear that one might be attracted through them to doctrines that are dangerous." 16

The fact that even Ibn Khaldun, who was not indebted to Greek philosophy as were other Muslim philosophers, was condemned reflects how powerful the hold of the orthodoxy was, especially in the legalistic trend. Al-Biruni, one of the greatest scientists among Muslims, was also subjected to similar religious denunciation. ${ }^{17}$

Ibn Khaldun and al-Biruni are particularly relevant here because the former made pivotal contributions in the field of sociology of history and the latter in the field of science, mathematics, astronomy, history and more. Given that Muslim scientists and scholars have provided leadership in the fields of knowledge in general and science in particular for such a long period of time, it would be reasonable to expect that they also made some contribution to statistics. Indeed, it appears that the works of Ibn Khaldun and al-Biruni did make such contributions to the fields of research methodology in general and statistics in particular, as connected to the development of modern statistics.

Connecting these historical dots might not have been possible without the seminal study of Robert F. Boruch, professor of education and statistics at the Wharton School of the University of Pennsylvania, who focused on the works of Ibn Khaldun and al-Biruni. ${ }^{18}$

Boruch's work grew out of a UNESCO conference on evaluation techniques, where the participants generally identified "the techniques of applied social research in general and statistical evaluation in particular [being] more compatible with western culture than eastern." 19 The goal of his paper was:

[T]o illuminate this concern in a limited way, notably by identifying early Arabic precedents for some of the 'modern' ideas implicit in methods of applied social research. ... The history of social research, including statistic, deserves serious intellectual attention on its own account. Kruskal and Mosteller ... and others have increased our understanding of the topic on relevant occidental literature. Eastern and Middle Eastern material has received far less attention than it deserves to judge from historians and philosophers such as Hacking ... and others. This is an effort to rectify the matter in a small way, using 
two remarkable works, Ibn Khaldun's Muqaddimah and al-Biruni's India..$^{20}$

According to Boruch, Ibn Khaldun's "work has been recognised as a progenitor of modern disciplines of sociology and human ecology by scholars" and al-Biruni's "works contain ideas pertinent to social statistics, applied social research, and numerical evidence." 21 Others have also studied the works of al-Biruni. Works by him "besides India have been analyzed by Eisenhard and Kennedy in the interest of discovering early predecessors to the contemporary measures of central tendency in statistical data. Some of the specific issues he considered fall often into territory now claimed by the pollster, the demographer, social scientist, statistician, and evaluation researcher." 22

After identifying and analysing traces of several basic statistical or quantitative methods, such as mean, relative frequency, correlation, causality, response bias, etc., Boruch asserts:

[T] here is sufficient evidence here to judge that some ideas underlying contemporary research methods, especially quantitative methods, were recognized by Ibn Khaldun and al-Biruni and were discussed. To judge by other commentators, there is evidence for the contention that Ibn Khaldun did go well beyond his own contemporaries in this respect. ... [I]t seems fair to regard both men as legitimate predecessors to the applied social researcher-conscientious models of what can be done to understand what happens, why it happens, and with what consequences. ${ }^{23}$

According to the renowned historian Arnold Toynbee, “... in the Prolegomena (Muqaddimah) to his Universal History, he (Ibn Khaldun) has conceived and formulated a philosophy of history which is undoubtedly the greatest work of its kind that has ever yet been created by any mind in any time or place." ${ }^{24}$ What is remarkable in this context is that Ibn Khaldun identified the Qur'an as the source of guidance and inspiration for his works.

When our discussion in the section on royal authority and dynasties has been studied and due critical attention given to it, it will be found to constitute an exhaustive, very clear, fully substantiated interpretation and detailed exposition of these sentences. We became aware of these things with God's help and without the instruction of Aristotle or the teaching of the Mobedhan (note: a Zoroastrian source). ${ }^{25}$

We, on the other hand, were inspired by God. He led us to a science whose truth we ruthlessly set forth. If I have succeeded in presenting 
the problems of this science exhaustively and in showing how it differs in its various aspects and characteristics from all other crafts, this is due to divine guidance. If, on the other hand, I have omitted some point, or if the problems have got confused with something else, the task of correcting remains for the discerning critic, but the merit is mine since I cleared and marked the way. 'God guides with his light whom He will' [al-Qur'an 16:68].

\section{Statistics in the Islamic Scriptures}

As Ibn Khaldun asserts that his work was rooted in Qur'anic guidance, in this part we explore how the notion of statistics has been dealt with in that text. Notably, as the Dictionary of Statistics: English-French-Arabic notes: the Arabic term for statistics, as used in modern statistics, is al-ihsa' or ilm al-ihsa' (the discipline of statistics). ${ }^{27}$ The term means: "to count, enumerate, calculate, compute, reckon." 28

That term is also used in the Qur'an in several places, ${ }^{29}$ notably in the sense of counting or measurement or simply taking account.

On the Day that Allah will raise them all up (again) and show them the Truth (and meaning) of their conduct. Allah has reckoned its (value) ahsahu - though they may have forgotten it, for Allah is Witness to all things. (58:6)

God, of course, does not need to gather such data or information, since He is Omniscient. However, in the human context, the importance and relevance of gathering data, an essential part of statistics, is undeniable. In the following verses the term ihsa' has been used not just in the sense of counting or measurement, but especially in the sense of census, corresponding to the notion of 'population.'

That He may know that they have (truly) brought and delivered the Messages of their Lord: and He surrounds (all the mysteries) that are with them, and takes account - ahsaa - of every single thing. (72:28)

And the Book (of Deeds) will be placed (before you); and you will see the sinful in great terror because of what is (recorded) therein; they will say, "Ah! woe to us! what a Book is this! It leaves out nothing small or great, but takes account - ahsaha - thereof!" They will find all that they did placed before them: And not one will your Lord treat with injustice. $(18: 49)$

Verily We shall give life to the dead, and We record that which they send before and that which they leave behind, and of all things have 
We taken account - ahsainahu - in a clear Book (of evidence). (36:12)

And all things have We preserved - ahsainahu - on record. (78:29)

The following verse takes the issue of gathering data much further as accuracy as well as avoidance of error are clearly emphasised.

He does take an account of them (all) - ahsaahum -, and has numbered them (all) exactly. (19:94)

While God is perfect and error-free, gathering data as accurately as possible and analysing the same for exactitude are vital in a human context, for which measurement of error is the logical conclusion. In the works of al-Biruni and Ibn Khaldun, who were inspired and guided by the Islamic scriptures, we see not just gathering particular sets of information or data, but also organising and analysing the data to evaluate its acceptability.

Complete and perfect knowledge is the domain of God. Lack of perfection and complete accuracy is the domain of homo sapiens. This recognition is especially relevant, because while human beings cannot act like God or achieve perfection and complete accuracy, the need to be aware of our errors in terms of their deviation from reality, and any possible measurement of such error, is vitally important.

Thy Lord does know that you stand forth (to prayer) nigh two-thirds of the night, or half the night, or a third of the night, and so does a party of those with thee. But Allah does appoint night and day in due measure He knows that you are unable to keep count-tuhsuhu - thereof. So He has turned to you (in mercy); read you, therefore, of the Qur'an as much as may be easy for you. He knows that there may be (some) among you in ill-health; others travelling through the land, seeking of Allah's bounty; yet others fighting in Allah's Cause, read you, therefore, as much of the Qur'an as may be easy (for you); and establish regular Prayer and give regular Charity; and loan to Allah a Beautiful Loan. And whatever good you send forth for your souls you shall find it in Allah's Presence,- yea, better and greater, in Reward and seek the Grace of Allah, for Allah is Oft-Forgiving, Most Merciful. (73:20)

Since God-like perfect counting or enumeration is not possible for human beings, there is a need to calculate or estimate-meanings also covered by the term al-ihsa'. Recognising errors or deviations is essential to such processes of calculation or estimation. Thus, it is not surprising that attention to such accuracy, 
especially when numbers, figures or sources are concerned, was well recognised by Ibn Khaldun.

Ibn Khaldun was extraordinarily sensitive to errors of many kinds in reporting. Recognizing that one must rely on a variety of sources whose reliability is unknown, he discourages simple acceptance of reports and identifies numerical information as being particularly susceptible to distortion:

"If one trusts ... information in its plain transmitted form ... he often cannot avoid stumbling and slipping and deviating from the path of truth.

This is especially the case with figures, either sums of money or soldiers, whenever they occur ... They offer a good opportunity for false information and constitute a vehicle for nonsensical statements." ${ }^{\prime 30}$

As Boruch points out, Ibn Khaldun cites the Qur'an for this sensitivity toward the evaluation of reported information.

To buttress the case that it is wrong to 'make a feast of untrue statements' as his antecedents and contemporaries did, he appealed to the Koran ...: 'They procure for themselves entertaining stories in order to lead others away from the path of God' and ends with the announcement that 'this is a bad enough business. ${ }^{31}$

In trying to separate fact from fiction and not accepting any report or data without evaluation or scrutiny, al-Biruni also appealed to the Qur'an to sustain his views. ${ }^{32}$

The fact that there are limits to our ability to count and measure is also recognised in the Qur'an, as in the following two verses:

And He gives you of all that you ask for. But if you count the favours of Allah, never will you be able to number them - tuhsuhaa. Verily, man is given up to injustice and ingratitude. (14:34)

If you would count up the favours of Allah, never would you be able to number them - tuhsuhaa: for Allah is Oft-Forgiving, Most Merciful. (16:18)

These verses hint at the gap between complete or perfect information, such as population, and what human beings have to contend with, i.e., a 'sample.' Of course, in such cases, such calculation would be 'estimation.' 
In the following verse, too, the term al-ihsa' has been used in the sense of approximation or estimation.

Then We roused them, in order to test which of the two parties was best at calculating - ahs $a$ - the term of years they had tarried! (18:12)

The term al-ihsa' in hadith has been mentioned specifically in the sense of estimation or measurement.

Narrated Abu Hurairah: Allah's Apostle said: "Calculate/estimate/ determine - Uhsu - the Crescent of Sha'ban for Ramadan." ${ }^{33}$

Narrated Hudhaifa: The Prophet (s) said: "Count - uhsuu - the number of people who have uttered (embraced) Islam ..." 34

In the Muqaddimah, Ibn Khaldun has used the same term in the sense of census. Referring to Ibn Battuta's account of a particular Indian monarch, Ibn Khaldun wrote:

He [Ibn Battuta] reported things about him that his listeners considered strange. That, for instance, when the ruler of India went on a trip, he counted [ahsa'] the inhabitants of his city, men, women, and children, and ordered that their requirements for (the next) six months be paid them out of his own income. ${ }^{35}$

The following verse where the word al-ihsa' has been used is of especial relevance; in the practical context of divorce, the believers are asked to count the number of menstrual cycles that must pass before divorce can be pronounced according to Islamic rules.

O Prophet! When you do divorce women, divorce them at their prescribed periods, and count (accurately) - ahsuu -, their prescribed periods: And fear Allah your Lord: and turn them not out of their houses, nor shall they (themselves) leave, except in case they are guilty of some open lewdness, those are limits set by Allah. And any who transgresses the limits of Allah, does verily wrong his (own) soul: you know not if perchance Allah will bring about thereafter some new situation. (65:1)

It is well-known that al-Khawarizmi devoted himself to the development of algebra in order to simplify the calculation of inheritance shares in accordance with Islamic rules. ${ }^{36}$ It is not surprising that the curiosity of Muslim scholars in applying algebra to linguistic studies led them to cryptography, where statistical methodology is vital. 
Al-Kindi (d. $870 \mathrm{AD}$ ) was a pioneer in cryptography, providing the first known recorded explanation of cryptanalysis in his work A Manuscript on Deciphering Cryptographic Messages. He is therefore credited as the father of cryptography. ${ }^{37}$ His book described "the use of several statistical techniques for cryptoanalysis. This book apparently antedates other cryptology references by several centuries, and it also predates writings on probability and statistics by Pascal and Fermat by nearly eight centuries." ${ }^{38}$ His work indicates that one of the common statistical methods, maximum likelihood, was well known in the Muslim world. Borelli et al explains his contribution in the following way:

In a natural language letters have a typical occurrence frequency (E appears $12 \%$ of an English clear text, say); this typical frequency is "inherited" by the corresponding cipher text letter, and so, after a few trials and some semantic aid, the cryptogram can be broken. The underlying method, called maximum likelihood, is typical of statistics, and was well known in the old Arab world: to this end the Aristotelian philosopher Al Kindi had prepared an accurate statistical description of the Arab language, obtained by sampling part of the Qur'an. Long forgotten in Europe, cryptography was re-born in Italy during Renaissance, but the lessons of the Arabs had been learnt, and it was well understood that a good cipher system should be able to 'cheat' statistics. ${ }^{39}$

Another example of a relevant contribution is provided by Ibn Sina, or Avicenna (d. 980 AD), in the area of drug development, which required concurrent control.

The central idea in clinical trials today is that of concurrent control: comparing the effects of treatments at the same time in a single experiment. This idea did not really find widespread practice until after the Second World War but there were, of course, many earlier examples. Some are reviewed by Pocock (1983) in his book and also by Lancaster (1994) and Gehan and Leman (1994), who suggest that the Islamic-Persian scholar Avicenna (980-1037) was an early proponent of the technique. ${ }^{40}$

A key aspect of statistics is the study of probability, a synonym of which is chance. Muslims have taken the notion of probability seriously because one of the major prohibitions in Islam involves maysir (gambling or games of chance).

They ask you concerning intoxicants and gambling. Say: In them is a great sin and some benefit for men. But the sin is greater than the benefit. (2:219) 
O you who believe! Intoxicants and gambling, (dedication of) stones and arrows are abomination of Satan's handiwork: Abstain from it so that you may prosper. Satan's plan is (but) to excite enmity and hatred between you, with intoxicants and gambling, and binder you from the remembrance of Allah, and from prayer: Will you not then abstain? (5:90-91)

Unfortunately, while in many areas of life, Muslims have been inspired by the Qur'an or Islamic precepts to deal with relevant problems and challenges, in regard to the issue of chance, beyond the insistence of the moral aspect of the prohibition, there has not been any specific attempt to study and develop the concept of chance or probability in an applied manner. This may be because theology in general approaches the issues of life and reality in the framework of certainty and conviction. This is especially true in traditional Islamic theology, where in matters of faith firm conviction (yaqeen) is expected and its opposite in the form of doubt/uncertainty (shakk or shubhah) or chance/probability (ihtimal or zann) is shunned.

Nonetheless, the notion of probability in a qualitative sense was noted and dealt with, even in the scriptural context, by Ibn Khaldun. This is in relation to narrations from the Prophet Muhammad. As Ibn Khaldun explains about hadith:

Another of the sciences of tradition is the knowledge of the norms that leading hadith scholars have invented in order to know the chains of transmitters, the (individual) transmitters, their names, how the transmission took place, their conditions, their classes, and their different technical terminologies. This is because general consensus makes it obligatory to act in accordance with information established on the authority of the Messenger of God. This requires probability for the assumption that the information is true. Thus, the independent student must verify all the means by which it is possible to make such an assumption. ${ }^{41}$

Explaining further about the role of probability in determining the acceptability of hadith ${ }^{42}$, Ibn Khaldun explained:

One must act only in accordance with those traditions of the Messenger of God that, in all probability, are true. How it is possible to assume probability must be investigated by independent study. One gets to (the assumption of probability) through knowledge of the probity and accuracy of the transmitters of traditions. Such knowledge is established through information obtained on the authority of religious leaders, which declares a transmitter to be reliable and free from unreliability or 
negligence. This shows us whether we should accept their (traditions) or reject them. ${ }^{43}$

Gradually, the problem-solving approach and perspective has waned; with the domination of mysticism and legalism, these aspects have been avoided to the extent that no functional approach and tool has been developed, especially in the quantitative arena. It is not surprising that in the modern conflict between religion and science, which should be alien to Islam, the debate continues as to whether God and chance are compatible or a scientific/rational minds must make a choice between God and chance. ${ }^{44}$

While Muslims made major contributions to the development of statistical concepts, it is important to recognise that much of it remained limited to the qualitative domain. Thus, in modern statistics, full of quantitative tools and methods, Muslims have remained disconnected from the legacy of their own contributions. It should not be surprising that modern works on the history of statistics, which generally cover the past 3-4 centuries, do not note any major contribution from Muslims.$^{45}$ Consider, for example, the field of Islamic finance, where models are being used and risks are being quantified. Notably, according to some researchers the term 'hazard', which is at the core of the notion of risk, is probably of Arabic origin.

According to Kendall, Maurice George (1956), it was brought to Europe at the time of the third Crusade and derived from the Arabic word 'al zhar', meaning a die. ${ }^{46}$

Yet, lacking any quantitative tools, we can speak about risk or uncertainty only in legalistic terms.

\section{Conclusion and Recommendations}

The contribution of Islamic civilisation to the field of mathematics is well known. ${ }^{47}$ It is only natural that statistics, as a practical, applied field intimately connected with mathematics, should also have played an important role in Islam. However, the praxis related to this field and how much it has developed has not been studied as extensively. It is also well recognised that Muslim scientists and scholars contributed pivotally to empirical investigation and research. There are also indications that Muslim scholars and scientists were aware of several important statistical methods. That would be considered natural, especially in light of the notion of al-ihsa' in the Qur'an. As explored in this paper, the Qur'anic term al-ihsa' covers a broad range of meaning and nuance that closely reflects the modern notion of statistics in the following sense: "the art and science of gathering, analysing and making inferences from data." It can also be argued that 
there is hardly any comparable scripture where pivotal thoughts corresponding to the modern field of statistics exist.

Boruch hoped that his pioneering work about the contribution of Muslims to the field of statistics would pave the way for a further study of the subject. In this paper, Boruch's presentation of evidence and arguments is further strengthened by the notion that the Qur'an contains specific terms and ideas that bound the notion of statistics to practical aspects of life. This neglected area of statistics in the legacy of Muslim history merits further research. The paper concludes by recommending that:

- Works on the history of science in the Muslim world include the contribution of Muslims to the field of statistics.

- Further investigations should empirically study the economic and social conditions and experience of Muslims throughout history by applying statistical and quantitative tools and methods.

- An initiative should be taken to publish an edited book or monograph focused on the historical contribution of Muslims to the field of statistics and quantitative study.

\section{Notes}

* Qazi M. Ali is Professor at the Department of Statistics and Operations Research, Aligarh Muslim University, India.

** Mohammad Omar Farooq is Associate Professor at the Department of Economics and Finance, University of Bahrain.

1. W. Wilcox, 'Definitions of Statistics,' Review of International Statistical Institute 3, no. 4 (1936): 388-99.

2. The New Encyclopedia Britannica (New York: Encyclopedia Britannica, 1994), 217.

3. E.L. Lehmann, 'Statistics: An Overview,' in Encyclopedia of Statistical Sciences, ed. S. Kotz and N. L. Johnson (New York: Wiley, 1988), 683-702.

4. R.A. Johnson, 'Statistics and Religious Studies,' in Encyclopedia of Statistical Sciences, ed. S. Kotz and N. L. Johnson (New York: Wiley, 1988), 679-83.

5. A.M. Hasofer, 'Random Mechanisms in Talmudic Literature,' Biometrica 54, no. 4 (1966): 316-21.

6. N.L. Rabinovitch, Probability and Statistical Inference in Ancient and Medieval Jewish Literature (Toronto: University of Toronto Press, 1973), 53.

7. L.F. Adams and A.C. Reucher, 'The Popular Critical View of the Isaiah in Light of Statistical Style Analysis,' Computer Studies 4, no. 1 (1973): 149-57.

8. A.M. Honroe, 'A Statistical Study of the Synoptic Problem,' Novum Testamentum 10, no. 4 (1968): 95-147. 
9. Johnson, 'Statistic and Religious Studies,' 679-80.

10. Ibid., 680 .

11. Ibid., 681.

12. R.E. Bee, 'Statistics and Source Criticism,' Vetus Testamentum 33, no. 5 (1983): 483-8; C.E. Carlston and D. Norlin, 'Once More: Statistics and Q,' Harvard Theological Review 64, no. 5 (1971): 59-78; Honore, 'The Synoptic Problem,': 95-147; C.B. Houk, 'A Statistical Linguistic Study of Ezekiel,' Zeit. Fur Altestamentliche Wissenschaft 93, no. 4 (1981): 76-84; J. Hoyrup, 'Sixth Century Initiative Probability: The Statistical Significance of a Miracle,' Historia Mathematica 10, no. 4 (1983): 80-3; S. Portnoy and D. Peterson, 'Biblical Texts and Statistical Analysis: Zechariah and Beyond,' Journal of Biblical Literature 103, no. 3 (1984): 11-21.

13. Imam Bukhari, Sahih al-Bukhari, trans. Muhammad Muhsin Khan, vol. 3 (Madinah: n.d.).

14. Imam Muslim, Sahih Muslim, trans. N. Khattab (Jeddah: Darussalam, 2007), 144.

15. S.M. Deen, Science Under Islam: Rise, Decline and Revival (London: Lulu Enterprises, 2007), 121. Notably, Khalifa was the title often adopted or used for these rulers. However, as khilafa was an institution based on 'representation and participation', these rulers should not be categorised as such because they do not reflect these principles.

16. Ibid., 123.

17. S.K. Hamarneh and M.A. Anees, Health sciences in early Islam: Collected Papers (Blanco: Zahra Publications, 1984), 181.

18. R. F. Boruch, 'Ideas About Social Research, Evaluation, and Statistics in Medieval Arabic Literature: Ibn Khaldun and al-Biruni,' Evaluation Review 8, no. 6 (1984): 823-42.

19. Ibid., 823.

20. Ibid., 823-4.

21. Ibid., 824 .

22. Ibid., 824-5.

23. Ibid., 841.

24. A. Toynbee, A Study of History: The Growths of Civilizations (New York: Oxford University Press, 1962), 321-8.

25. Ibn Khaldun, The Muqaddimah, trans. F. Rosenthal (Princeton: Princeton University Press, 1969), 41.

26. Ibid., 42.

27. A. Alsiddiqi, Dictionary of Statistics: English-French-Arabic (Beirut: Dar E-Rateb, 2001), 243.

28. R. Baalbaki, Al-Mawrid: A Modern Arabic-English Dictionary (Beirut: Dar ElIlm Lilmalayin, 1988), 51.

29. All the translations of the Qur'anic verses are taken from, with slight modification if warranted, A. Yusuf Ali, The Holy Qur'an: Text, Translation and Commentary, $2^{\text {nd }}$ ed. (New York: Tahrike Tarsile Qur'an, 1988).

30. Ibn Khaldun, Muqaddimah, 826,

31. Ibid., 826.

32. Ibid., 826 . 
33. At-Tirmidhi, Jami at-Tirmidhi, trans. Abu Khaliyl (Houston: Dar-us-Salam Publications, 2007), 147.

34. A. Ibn Hanbal, Musnad Ahmad (Beirut: Dar Ihya at-Turath al-Arabi, 1993), 22875 .

35. Ibn Khaldun, Muqaddimah, 145.

36. S. Gandz, 'The Algebra of Inheritance: A Rehabilitation of Al-Khuwarizmi,' Osiris 5, no. 5 (1938): 319-91.

37. S. Singh, The Code Book: The Science of Secrecy from Ancient Egypt to Quantum Cryptography (New York: Anchor, 2000), 156.

38. http://en.wikipedia.org/wiki/Al-Kindi

39. M. Borelli, A. Fioretto, A. Sgarro and Luciana Zuccheri, 'Cryptography and Statistics: A Didactical Project,' paper presented at the $2^{\text {nd }}$ International Conference on the Teaching of Mathematics, July 1-6, 2002, Crete, Greece, retrieved on August 26, 2009 from http://www.math.uoc.gr/ ictm2/Proceedings/ pap265.pdf.

40. S. Senn, Statistical Issues in Drug Development (West Sussex: WileyInterscience, 2008), 20.

41. Ibn Khaldun, Muqaddimah, 11.

42. For a detailed exposition of the issues related to the probabilistic understanding of hadith, see M.O. Farooq, Toward Our Reformation: From Legalism to ValueOrientation in Islamic Law and Jurisprudence (Herndon: International Institute of Islamic Thought, 2011).

43. Ibn Khaldun, Muqaddimah, 55.

44. D.J. Bartholomew, God of Chance (London: SCM Press, 1984), 78.

45. S.M. Stigler, The History of Statistics: The Measurement of Uncertainty before 1900 (Cambridge: Belknap Press, 1990); S.M. Stigler, Statistics on the Table: The History of Statistical Concepts and Methods (Cambridge MA: Harvard University Press, 2002).

46. Y. Dodge, The Concise Encyclopedia of Statistics (New York: Springer, 2008), 430.

47. A. Hald, A History of Probability and Statistics and Their Applications Before 1750 (Hoboken, NJ: Wiley, 2005). 